\title{
Tingkat Kekasaran Permukaan Roda Gigi Lurus Baja St 37 Pada Kecepatan Putaran Spindel, Variasi Feeding, dan Depth of Cut
}

\author{
Prasetio Dian Fasesa ${ }^{1)}$, Suwarno ${ }^{2)}$, dan Tuwoso ${ }^{3)}$ \\ 1,2,3 Mahasiswa Program Studi S1 Pendidikan Teknik Mesin Jurusan Teknik Mesin \\ ${ }^{1,2,3}$ Fakultas Teknik Universitas Negeri Malang \\ 1,2,3 Jalan Semarang No. 5, Malang 65145 \\ Email:fasesanote@gmail.com ${ }^{1}$
}

\begin{abstract}
Abstrak: Di era modern saat ini sudah banyak orang yang bisa membuat sebuah roda gigi, tetapi hasilnya beraneka ragam mulai dari halus, kasar, dan ada pula yang tidak rapi. Perbedaan hasil tersebut dikarenakan proses produksi yang kurang teliti saat pengerjaannya. Karena bukan hanya mesin yang dapat mempengaruhi hasil kerja, namun proses pengoperasian mesin juga sangat berpengaruh terhadap hasil kerja. Tujuan penelitian ini adalah untuk mengetahui tingkat kekasaran permukaan roda gigi lurus baja st 37 pada kecepatan putaran spindle, variasi feeding, dan depth of cut.

Penelitian ini menggunakan metode eksperimen untuk mengetahui pengaruh kecepatan putaran spindle, variasi feeding dan depth of cut pada proses milling pembuatan roda gigi lurus baja st 37 . Penelitian ini mengamati akibat perubahan suatu metode dan kemudian hasilnya dibandingkan. Bentuk dalam eksperimen ini dijelaskan dalam desain penelitian dimana observasi dilakukan satu kali yaitu sesudah eksperimen. Kecepatan putaran spindle yang digunakan adalah $150 \mathrm{Rpm}, 235 \mathrm{Rpm}$, dan $375 \mathrm{Rpm}$ dengan kecepatan pemakanan (feeding) $22 \mathrm{~mm} /$ menit, $35 \mathrm{~mm} / \mathrm{menit}$, dan $56 \mathrm{~mm} / \mathrm{menit}$ dengan kedalaman pemakanan (depth of cut) $0.20 \mathrm{~mm}, 0.35 \mathrm{~mm}$, dan $0.50 \mathrm{~mm}$. Penelitian dilakukan di Bengkel Mesin dan CNC VEDC Malang. Kemudian alat uji kekasaran permukaan menggunakan Surface Roughness Tester merek Mitutoyo milik Laboratorium Teknik Mesin, Jurusan Teknik Mesin, Fakultas Teknik, Universitas Negeri Malang. Pisau frais yang digunakan adalah pisau modul dengan diameter 2.5 inch. Teknik analisis data yang digunakan adalah deskriptif kuantitatif.

Berdasarkan hasil penelitian dapat diartikan bahwa semakin tinggi kecepatan putaran spindle maka nilai kekasaran permukaan semakin rendah. Semakin tinggi feeding nilai kekasaran akan semakin tinggi. Begitu pula semakin tinggi depth of cut maka nilai kekasaran juga akan semakin tinggi. Nilai rata-rata kekasaran permukaan paling rendah adalah $0.17 \mu \mathrm{m}$ pada kecepatan putaran spindel $375 \mathrm{rpm}$, depth of cut $0.20 \mathrm{~mm}$, dan feeding $22 \mathrm{~mm} / \mathrm{menit}$. Sedangkan nilai rata-rata kekasaran permukaan paling tinggi adalah $0.465 \mu \mathrm{m}$ pada kecepatan putaran spindel $150 \mathrm{rpm}$, depth of cut $0.50 \mathrm{~mm}$, dan feeding $56 \mathrm{~mm} / \mathrm{menit}$. Oleh karena itu tingkat kekasaran permukaan sangat dipengaruhi oleh kecepatan putaran spindle, kecepatan pemakanan (feeding), dan kedalaman pemakanan (depth of cut).
\end{abstract}

Kata kunci: kecepatan putaran spindle, kecepatan pemakanan (feeding), kedalaman pemakanan (depth of cut), roda gigi lurus, kekasaran permukaan

Pesatnya perkembangan teknologi saat ini membawa akibat bagi berkembangnya alat pendukung teknologi berbasis pemesinan. Adanya peningkatan ketepatan, ketelitian, dan kehandalan serta ketahanan alat yang sering digunakan dalam suatu proses semakin menjadi tantangan, salah satunya dalam dunia manufaktur. Mesin Milling atau mesin frais ditemukan oleh Eli Whitney sekitar tahun 1818. Mesin frais ini melakukan operasi produksi suku cadang duplikat yang pertama dengan pengendali secara mekanik arah dan gerakan potong dari perkakas mata potong jamak yang berputar.

Tingkat kehalusan permukaan merupakan peranan penting dalam perencanaan suatu komponen mesin khususnya yang menyangkut masalah gesekan, pelumasan, keausan, tahanan terhadap kelelehan, dan sebagainya (Munadi, 1998:303).

Menurut Budiman dan Richard (2007) Spindle dinaikkan, feeding dan depth of cut tetap akan menghasilkan kekasaran permukaan yang halus. Berdasarkan penelitian bahwa semakin besar kecepatan putaran spindle yang digunakan maka akan semakin kecil nilai nilai kekasaran permukaannya. Di era modern saat ini sudah banyak orang yang bisa membuat sebuah roda gigi, tetapi hasilnya beraneka ragam mulai dari halus, kasar, dan ada pula yang tidak rapi. Perbedaan hasil tersebut dikarenakan proses produksi yang kurang teliti saat pengerjaannya. Sehingga bukan hanya mesin yang dapat mempengaruhi hasil kerja, namun proses pengoperasian mesin juga sangat berpengaruh terhadap hasil kerja.

Pada umumnya pembuatan roda gigi menggunakan mesin frais horizontal, tetapi disisi lain pembuatan roda gigi juga dapat dilakukan di mesin frais vertikal. Produk yang dihasilkan dan waktu yang dibutuhkan dalam pengerjaan dari kedua mesin frais tersebut sama, yang membedakan adalah pada saat proses pengerjaannya mesin frais vertikal dengan menggerakan spindle dengan variasi putaran spindle, feeding atau kecepatan pemakanan benda kerja dan depth of cut. Berdasarkan latar belakang 
yang telah dipaparkan penelitian ini bertujuan untuk mengetahui tingkat kekerasan roda gigi dengan variasi kecepatan putaran spindel, feeding, dan depth of cut. Selaras dengan tujuan tersebut, maka penelitian ini diberi judul "Tingkat Kekasaran Permukaan Roda Gigi Lurus Baja St 37 pada Kecepatan Putaran Spindel, Variasi Feeding, dan Depth of Cut".

Berdasarkan rumusan masalah di atas, maka didapatkan tujuan penelitian sebagi berikut : 1) Untuk mengetahui tingkat kekasaran permukaan profil roda gigi lurus pada kecepatan putaran spindel $150 \mathrm{rpm}, 235 \mathrm{rpm}$ dan $375 \mathrm{rpm}$. 2) Untuk mengetahui tingkat kekasaran permukaan profil roda gigi lurus yang disayat dengan depth of cut $0,20 \mathrm{~mm}, 0,35 \mathrm{~mm}$, dan 0,50 mm. 3) Untuk mengetahui tingkat kekasaran permukaan profil roda gigi lurus yang disayat dengan feeding $22 \mathrm{~mm} / \mathrm{menit}, 35$ $\mathrm{mm} /$ menit, dan $56 \mathrm{~mm} /$ menit. 4) Untuk mengetahui tingkat kekasaran permukaan profil roda gigi lurus yang disayat dengan variasi kecepatan putaran spindle, variasi feeding, dan variasi depth of cut.

\section{METODE PENELITIAN}

Penelitian ini mengunakan metode penelitian kuantitatif eksperimental. Penelitian eksperimental adalah metode penelitian yang digunakan untuk mencari pengaruh kekuatan tertentu terhadap yang lain dalam kondisi yang terkendalikan. Variable bebas pada penelitian ini adalah: 1) kecepatan putaran spindle, 2) kecepatan pemakanan (feeding), dan 3) kedalaman pemakanan (depth of cut). Variabel terikat dalam penelitian ini yaitu nilai kekasaran permukaan baja ST 37. Variabel control dalam penelitian ini adalah: 1) Pisau Modul 2,5, 2) Kecepatan Putaran Spindel, 3) Kecepatan Pemakanan (feeding), 4) Kedalaman Pemakanan (depth of cut), dan 5) Cairan pendingin (coolant).

Instrumen penelitian yang digunakan adalah lembar observasi yang berisi nilai kehalusan permukaan baja ST 37 menggunakan putaran spindel yaitu $178 \mathrm{rpm}, 310 \mathrm{rpm}$, dan $450 \mathrm{rpm}$, kecepatan pemakanan (feeding) 20 feed/menit, 40 feed/menit, dan $60 \mathrm{feed} / \mathrm{menit}$, dan juga menggunakan kedalaman pemakanan (depth of cut) 0,20 $\mathrm{mm}, 0,35 \mathrm{~mm}$, dan 0,50 mm. Prosedur pengumpulan data pada penelitian ini adalah sebagai berikut: 1) persiapan specimen, 2) proses pengefraisan, 3) pengumpulan data.

\section{HASIL DAN PEMBAHASAN}

Hasil uji kekasaran permukaan roda gigi lurus baja st 37 juga disajikan dalam bentuk grafik batang.

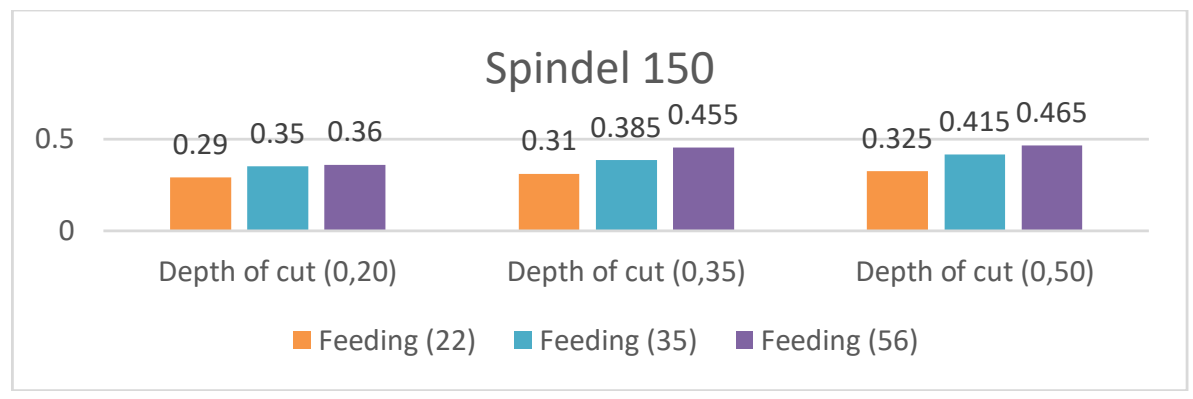

Gambar 1. Grafik S

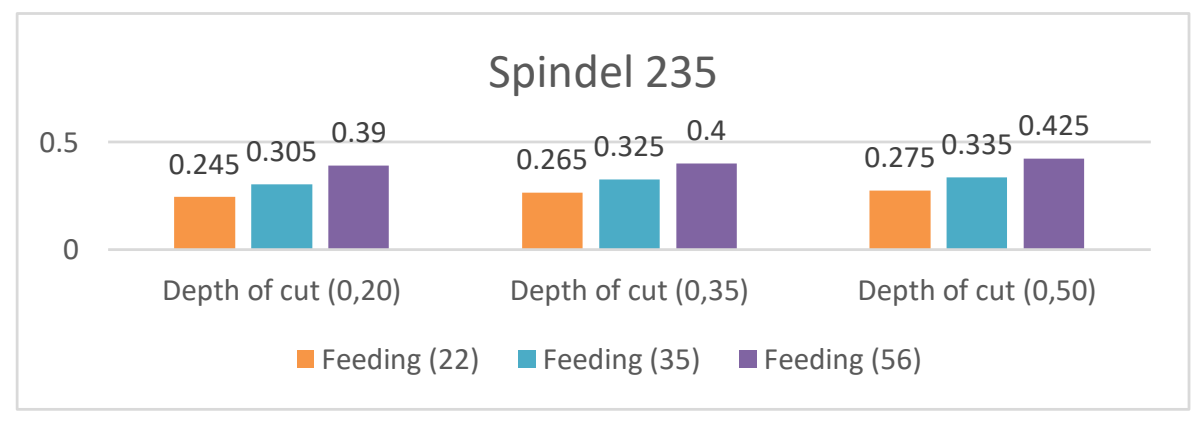

Gambar 2. Grafik S 


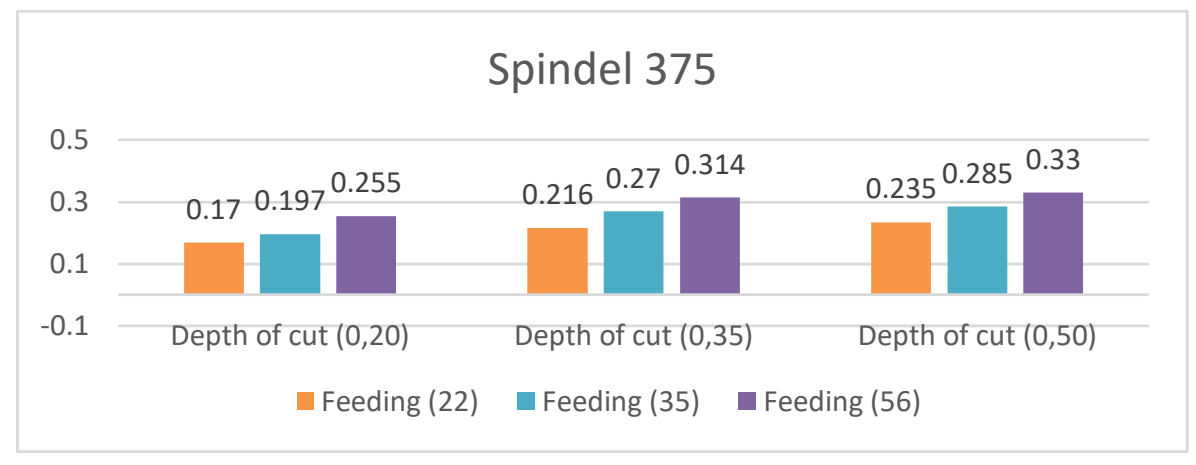

\section{Gambar 3. Grafik S}

Kekasaran permukaan terbesar terjadi pada putaran spindel $150 \mathrm{rpm}$, kedalaman pemakanan (depth of cut) 0,50 mm, dan kecepatan pemakanan (feeding) 56 feed/min. Sedangkan kekasaran permukaan terendah terjadi pada kecepatan putaran spindel $375 \mathrm{rpm}$, kedalaman pemakanan (depth of cut) $0,20 \mathrm{~mm}$, dan kecepatan pemakanan (feeding) $22 \mathrm{feed} / \mathrm{min}$.

Pada variasi kecepatan potong yang digunakan ini terdapat perbedaan tingkat kekasaran yang jelas sehingga hasil yang diperoleh dari kekasaran permukaan yang paling rendah adalah dengan menggunakan kecepatan putaran spindle 375 rpm pada kecepatan pemakanan (feeding) $22 \mathrm{~mm} / \mathrm{menit}$ dan kedalaman pemakanan (depth of cut) $0,20 \mathrm{~mm}$, namun ketika variasi kecepatan putaran spindle, feeding, dan depth of cut menggunakan parameter yang lebih rendah, hasil kekasarannya bertambah menjadi tinggi.

Kondisi variasi kecepatan putaran spindle, feeding, dan depth of cut memiliki keterbatasan, artinya semakin tinggi kecepatan putaran spindle dan semakin kecil kecepatan pemakanan (feeding) dan kedalaman pemakanan (depth of cut) maka akan dapat mengakibatkan penyempitan luas penampang pemakanan dan penurunan gaya potong. Penyempitan luas penampang pemakanan dan penurunan gaya potong akan berpengaruh terhadap kualitas kekasaran permukaan. Hal ini diperkuat dengan adanya pernyataan Setiyana (2005: 23) bahwa kecepatan potong yang tinggi akan menurunkan rasio pemampatan geram dan penyempitan luas penampang pemakanan. Pemampatan geram dan penyempitan luas penampang pemakanan berpengaruh pada kualitas permukaan.

Menurut Syamsir (1989) juga mengatakan bahwa kualitas permukaan potong tergantung pada kondisi pemotongan, misalnya kecepatan potong yang rendah dengan feed dan depth of cut yang besar akan menghasilkan permukaan kasar (roughing) sebaliknya kecepatan potong tinggi dengan feed dan depth of cut kecil menghasilkan permukaan yang halus. Pernyataan tersebut sejalan dengan hasil penelitian yang sudah dilakukan. Hasil penelitian terdahulu dari Ganjar (2005) juga menyatakan bahwasanya kecepatan potong, laju pemakanan, kekerasan benda kerja dan kedalaman pemotongan secara statistic mempunyai pengaruh yang signifikan terhadap kekasaran permukaan. Berdasarkan analisis data hasil penelitian yang telah dilakukan, maka didapat pembahasan sebagai berikut:

\section{A. Perbedaan Tingkat Kekasaran Permukaan Profil Roda Gigi Lurus pada Variasi Kecepatan Putaran Spindel}

Pada variasi kecepatan potong yang digunakan ini terdapat perbedaan tingkat kekasaran yang jelas sehingga hasil yang diperoleh dari kekasaran permukaan yang paling rendah adalah dengan menggunakan kecepatan putaran spindel $375 \mathrm{rpm}$ pada kecepatan pemakanan (feeding) $22 \mathrm{~mm} /$ menit dan kedalaman pemakanan (depth of cut) $0,20 \mathrm{~mm}$, namun ketika variasi kecepatan putaran spindel menggunakan parameter yang lebih rendah, hasil kekasarannya bertambah menjadi tinggi.

Kondisi variasi kecepatan putaran spindel, feeding, dan depth of cut memiliki keterbatasan, artinya semakin tinggi kecepatan putaran spindel dan semakin kecil kecepatan pemakanan (feeding) dan kedalaman pemakanan (depth of cut) maka akan dapat mengakibatkan penyempitan luas penampang pemakanan dan penurunan gaya potong. Penyempitan luas penampang pemakanan dan penurunan gaya potong akan berpengaruh terhadap kualitas kekasaran permukaan. Hal ini diperkuat dengan adanya pernyataan Setiyana (2005: 23) bahwa kecepatan potong yang tinggi akan menurunkan rasio pemampatan geram dan penyempitan luas penampang pemakanan. Pemampatan geram dan penyempitan luas penampang pemakanan berpengaruh pada kualitas permukaan.

Menurut Syamsir (1989) juga mengatakan bahwa kualitas permukaan potong tergantung pada kondisi pemotongan, misalnya kecepatan potong yang rendah dengan feed dan depth of cut yang besar akan menghasilkan permukaan kasar (roughing) sebaliknya kecepatan potong tinggi dengan feed dan depth of cut kecil menghasilkan permukaan yang halus. Pernyataan tersebut sejalan dengan hasil penelitian yang sudah dilakukan. Hasil penelitian terdahulu dari Ganjar (2005) juga 
menyatakan bahwasanya kecepatan potong, laju pemakanan, kekerasan benda kerja dan kedalaman pemotongan secara statistik mempunyai pengaruh yang signifikan terhadap kekasaran permukaan.

\section{B. Perbedaan Tingkat Kekasaran Permukaan Profil Roda Gigi Lurus pada Variasi Kedalaman Potong}

Tiga parameter utama pada setiap proses pemesinan frais adalah kecepatan putaran spindle, kecepatan pemakanan (feeding), dan kedalaman pemakanan (depth of cut). Factor yang lain seperti bahan benda kerja dan jenis pisau yang digunakan sebenarnya juga memiliki pengaruh yang cukup besar, tetapi tiga parameter di atas adalah bagaian yang dapat diatur oleh operator secara langsung pada mesin frais.

Penelitian sebelumnya yang sudah dilakukan oleh Alfatih (2010) bahwa kedalaman pemotongan dan kecepatan pemakanan mempunya pengaruh yang positif terhadap kekasaran permukaan. Sedangkan kecepatan pemotongan berpengaruh negative dan didapat kekasaran permukaan yang lebih halus pada proses down milling daripada up milling.

Menurut Wahyu Budiarto (2013) kenaikan cutting speed dan depth of cut yang konstan akan naiknya amplitude getaran sehingga permukaan benda kerja akan semakin kasar. Hal ini menunjukkan bahwa cutting speed dan depth of cut berpengaruh secara signifikan terhadap amplitude getaran yang terjadi pada proses pemesinan dan menyebabkan pada kualitas akhir dari permukaan benda kerja. Dalam penelitian (Romiyadi dkk, 2012) menyatakan perubahan putaran spindle, gerakan pemakanan dan kedalaman potong pada proses pemesinan akan menyebabkan kekasaran produk yang dihasilkan. Kekasaran produk yang terjadi terbagi menjadi dua bentuk 1) permukaan yang kasar (roughness) dan 2) permukaan yang bergelombang (waviness)

Temuan pada penelitian ini menjelaskan bahwa adanya pengaruh kedalaman potong terhadap hasil kekasaran permukaan benda kerja. Artinya pada variasi kedalaman pemakanan yang digunakan ini terdapat perbedaan tingkat kekasaran permukaan yang jelas. Kalpakjian dan Schmid R. Steven (2005) mengatakan bahwa parameter yang sangat menentukan kekasaran permukaan adalah kedalaman pemakanan (depth of cut), laju pemakanan (feeding) dan kecepatan potong (spindel).

Hal ini dimungkinkan pada penelitian yang dilakukan, penggunaan kedalaman pemakanan yang berbeda ketebalannya. Yaitu menggunakan kedalaman potong $0,20 \mathrm{~mm}, 0,35 \mathrm{~mm}$, dan $0,50 \mathrm{~mm}$. penelitian ini mendapatkan hasil bahwa perbedaan tingkat ketebalan menghasilkan kekasaran permukaan yang berbeda pula.

\section{Perbedaan Tingkat Kekasaran Permukaan Profil Roda Gigi Lurus pada Variasi Kecepatan Pemakanan}

Pada hasil penelitian yang diperoleh dapat diketahui bahwa ada perbedaan tingkat kekasaran permukaan pada variasi kecepatan putaran spindle, feeding, dan depth of cut. Dari hasil pengujian kekasaran permukaan dengan Surface Roughness Tester diperoleh nilai tingkat kekasaran permukaan yang paling rendah terdapat pada kecepatan putaran spindle 375 rpm, kecepatan pemakanan (feeding) $22 \mathrm{~mm} /$ minute, dan kedalaman pemakanan (depth of cut) 0,20 mm, sedangkan nilai tingkat kekasaran permukaan yang paling tinggi terdapat pada kecepatan putaran spindle $150 \mathrm{rpm}$, kecepatan pemakanan (feeding) 56 $\mathrm{mm} /$ minute, dan kedalaman pemakanan (depth of cut) $0,50 \mathrm{~mm}$.

Feeding yang semakin kecil akan memperpendek jarak pemindahan pada setiap putaran, sehingga kekasaran permukaan yang dihasilkan semakin kecil pula. Pengaruh nyata feeding terhadap kekasaran permukaan tersebut disebabkan oleh peningkatan gaya potong pada saat proses pemotongan.

Dalam proses pemesinan energy pemotongan muncul pada waktu pahat melakukan penyayatan benda kerja. Energy pemotongan berpengaruh terhadap gaya potong yang terjadi. Feeding yang besar membutuhkan energy pemotongan yang besar, oleh karena itu gaya potong yang muncul pada waktu penyayatan dengan feeding besar juga akan besar. Akibat adanya gaya potong yang besar ini akan menimbulkan getaran pada pahat dan benda kerja secara langsung saling kontak. Getaran inilah yang akhirnya menimbulkan gelombang-gelombang yang tidak beraturan pada permukaan benda kerja, sehingga pada waktu dilakukan pengukuran kekasaran permukaan akan terlihat seperti gunung-gunung dan lembah pada permukaan seperti yang ditambilkan pada Gambar 2.4 . Getaran ini yang menyebabkan permukaan benda kerja menjadi lebih kasar dan jika diukur dengan menggunakan surface roughness tester akan menghasilkan nilai kekasaran permukaan $\left(R_{a}\right)$ yang tinggi.

Semakin besarnya gerak pemakanan (feeding) yang digunakan akan menyebabkan penumpukan lapisan material pada ujung pahat atau pisau (built-up edge). Menurut Taufik Rochim (1993:124) pada kecepatan potong atau kecepatan pemakanan rendah built-up edge yang terbentuk relatif kecil atau bahkan tidak terbentuk. Kalpakjian (1985:473) menambahkan, beberapa factor yang harus digaris bawahi yaitu, kecenderungan dari pembentukan built-up edge bisa dikurangi dengan mengurangi kedalaman potong (depth of cut), menambah sudut garuk (rake angel), menggunakan pahat dengan radius kecil (small tip radius) dan menggunakan cairan pendingin yang efektif.

Meningkatnya gerak pemakanan (feeding) juga akan menyebabkan jarak dalam arah pemakanan (feed mark) dari satu mata potong yang berputar secara konstan akan semakin panjang, sehingga menyebabkan permukaan benda kerja semakin kasar. Hal ini disebabkan arah pahat potong yang bergerak secara sikloidal sehingga dalam proses pemotongan menghasilkan bentuk geram yang berbeda. Feeding yang kecil menghasilkan bentuk geram kontinyu (chip curl), sedangkan feeding yang 
besar akan menghasilkan bentuk geram yang kontinyu. Jadi pemakaian feeding yang rendah akan menghasilkan permukaan yang halus.

Oleh karena itu pada waktu diadakan pengukuran kekasaran permukaan, nilai kekasaran permukaan $\left(R_{a}\right)$ yang paling besar dihasilkan oleh specimen yang disayat dengan feeding yang besar dan kekasaran permukaan $\left(R_{a}\right)$ yang terkecil dihasilkan oleh specimen yang disayat dengan feeding yang terkecil. Hal ini sesuai dengan pendapat Kalpakjian (1985:514) yang mengatakan bahwa pada saat pahat bergerak sepanjang benda kerja, akan meninggalkan profil spiral pada permukaan benda kerja yang disebut feed mark. Feeding yang besar akan menghasilkan permukaan yang kasar, tetapi feeding yang kecil akan menghasilkan permukaan yang halus. Berdasarkan penelitian juga didapat bahwa kecepatan putaran spindle mempunyai pengaruh yang signifikan terhadap kekasaran permukaan benda kerja. Dengan pemakaian kecepatan putaran spindle (spindle speed) yang tinggi maka kekasaran permukaan yang dihasilkan semakin halus atau kekasaran permukaan $\left(R_{a}\right)$ yang dihasilkan kecil tetapi jika memakai kecepatan putaran spindle (spindle speed) yang rendah, maka kekasaran permukaan $\left(R_{a}\right)$ yang dihasilkan semakin besar atau kasar.

Jika menggunakan kecepatan putaran spindle yang tinggi maka geram yang dihasilkan tidak retak/putus sehingga menghasilkan permukaan yang halus. Menurut Budiman dan Richard (2007) Spindle dinaikkan, feeding dan depth of cut tetap akan menghasilkan kekasaran permukaan yang halus. Berdasarkan penelitian bahwa semakin besar kecepatan putaran spindle yang digunakan maka akan semakin kecil nilai nilai kekasaran permukaannya. Tetapi factor yang paling besar pengaruhnya terhadap hasil kekasaran permukaan $\left(R_{a}\right)$ adalah feeding $(f)$, sedangkan spindle speed $(n)$ paling kecil pengaruhnya. Menurut Munadi (1988) permukaan yang kasar berbentuk gelombang pendek yang tidak teratur dan terjadi karena getaran pisau (pahat) potong atau proporsi yang kurang tepat dari permukaan $($ feed $)$ pisau potong dalam proses pembuatannya. Sedangkan permukaan yang bergelombang mempunyai bentuk gelombang yang lebih panjang dan tidak teratur yang terjadi karena beberapa factor misalnya posisi senter yang tidak tepat, adanya gerakan tidak lurus (nonliniear) dari pemakanan (feed), dan getaran mesin.

Serope (2002) juga mengatakan bahwa parameter yang sangat menentukan kekasaran permukaan adalah kedalaman pemakanan (depth of cut), kecepatan pemakanan (feeding), dan kecepatan potong (cutting speed). Menurut Sumbodo (2008) bahwa salah satu factor yang menentukan baik buruknya kualitas hasil pengerjaan proses frais adalah bentuk/geometri permukaan atau bidang-bidang utama dari alat potong (cutter) frais itu sendiri.

\section{SARAN}

Berdasarkan kesimpulan yang diperoleh, beberapa hal yang perlu ditindak lanjuti antara lain :

1. Industri dapat menjadikan hasil dari penelitian ini sebagai alternatif untuk menerapkan feeding yang rendah $22 \mathrm{~mm} / \mathrm{menit}$ daripada feeding $35 \mathrm{~mm} /$ menit dan $56 \mathrm{~mm} /$ menit karena rata-rata tingkat kekasaran permukaan benda kerja menggunakan feeding $22 \mathrm{~mm} /$ menit paling rendah daripada rata-rata tingkat kekasaran permukaan benda kerja menggunakan feeding 35 $\mathrm{mm} /$ menit dan $56 \mathrm{~mm} / \mathrm{menit}$ sehingga hasil pembuatan roda gigi akan semakin optimal. Hal ini karena kebanyakan industry kurang memperhatikan kualitas permukaan dari hasil produksi. Jadi bukan hanya mesin saja yang mempengaruhi hasil kerja, namun proses pengoperasian mesin yang lebih berpengaruh terhadap kualitas hasil kerja;

2. Siswa SMK dan mahasiswa dapat menggunakan hasil dari penelitian ini sebagai acuan untuk menerapkan kecepatan putaran spindle yang tinggi $375 \mathrm{rpm}$ daripada kecepatan putaran spindle $150 \mathrm{rpm}$ dan $235 \mathrm{rpm}$ karena rata-rata tingkat kekesaran permukaan yang paling baik adalah pada kecepatan putaran yang tinggi. Namun perlu diketahui bahwa jenis pahat, cairan pendingin, dan komposisi bahan benda kerja juga mempengaruhi hasil kekasaran permukaan benda kerja;

3. Peneliti selanjutnya, dapat menggunakan hasil penelitian ini untuk menambah kajian pustaka tentang tingkat kekasaran roda gigi lurus baja st 37 pada kecepatan putaran spindel, variasi feeding, dan depth of cut. Namun juga bisa ditambah variasi jenis pahat, cairan pendingin, dan jenis komposisi bahan benda kerja yang lainnya. Kemudian agar penelitiannya mendapatkan hasil yang optimal dan mendapatkan data yang homogen, saat pengambilan data nilai kekasarannya perlu dilakukan berulang-ulang pada satu sampel. Hal ini dimaksudkan untuk mendapatkan data yang falid dari satu sampel benda kerja, jadi nilai kekasaran yang muncul tidak karena factor kebetulan.

\section{DAFTAR RUJUKAN}

A Muin, S. 1989. Dasar-dasar Perancangan Perkakas dan Mesin Perkakas. Jakarta: Rajawali.

Kalpakjian, Serope and Scmid R S. 2002. Manufacturing Engineering and Technology Fourth Edition. London : Prentice Hall.

Kalpakjian, S. 1985. Manufacturing Processes for Engineering Materials. Canada: Addisonn-Wesley

Kiswanto, G. 2005. Pengaruh Parameter Pemesinan Terhadap Kualitas Permukaan Baja DF-3 (AISI 01) yang Dikeraskan, Jurnal Teknologi Edisi No. 3. ISSN 0215-1685. (Online)

(http://www.scribd.com/document_download_direct_25351973) diakses 10 april 2017.

Munadi, S. 1988. Kualitas Permukaan Logam. Yogyakarta: Angkasa

Munadi, S. 1988. Panduan Pengajar Buku Dasar-Dasar Metrologi Industri. Jakarta: Proyek Pengembangan Lembaga Pendidikan Tenaga Kependidikan. 
Rochim, T. 1993. Teori dan Teknologi Proses Pemesinan. Jakarta: Higher Education Development Support Project.

Rochim, T. 2001. Spesifikasi, Metrologi, \& Kontrol Kualitas Geometrik. Bandung: ITB.

Romiyadi dan Emon, A. 2012. Pengaruh Parameter Kecepatan Pemakanan Terhadap Getaran Mesin Perkakas Pada Proses Up Milling Dan Down Milling Menggunakan Mesin Frais Universal Knuth UFM 2. Jurnal Ilmiah Sains Jerapan 5, (1). Hal 1-37 (Online) dalam Teknobiologi.

Setiyana, Budi. 2005. Pengaruh Kecepatan Potong pada Proses Pemesinan Kecepatan Tinggi Terhadap Geometrid dan Kekerasan Geram Untuk Beberapa Geram dengan Variasi Nilai Kekuatan Tarik. (Online),

(http://eprints.undip.ac.id/1662/1/pengaruh_kecepatan_potong_pada_proses_pemesinan_kecepatan_tinggi_doc.pdf) diakses 10 mei 2017.

Wahyu Budiarto. 2013. Pengaruh Cutting Speed Dan Depth Of Cut Kondisi Chatter Terhadap Kekasaran Permukaan Benda Kerja Proses Bubut. Jurusan Teknik Mesin Universitas Brawijaya. 